\title{
A Milestone for the Millennium: One Hundred Issues and Onwards
}

\begin{abstract}
Theatre Quarterly ceased publication after forty issues in 1981. New Theatre Quarterly picked up the threads in 1985, and happily continues publication after reaching this, its sixtieth issue, on the eve of the millennium. One hundred editions of the two journals inextricably linked by continuity of editorship, policy, and even format - called for some editorial reflections on past and future, in addition to our more utilitarian offering of cumulative indexes later in this issue. Here, then, the editors of New Theatre Quarterly throughout its run reflect from differing but complementary perspectives on the history and the future of both journals, and what they have meant to their own lives and careers. Simon Trussler was one of the founding editors of the original Theatre Quarterly, having also worked on the 'little' theatre magazines Prompt and Encore, and then served for five years as theatre critic of the weekly review, Tribune. A prolific author and editor in the field, his recent Cambridge Illustrated History of British Theatre was runner-up for the George Freedley Award of the American Theatre Libraries Association. For ten years from 1987 he taught in the Drama Department at Goldsmiths College, and was appointed Reader in Drama in the University of London in 1990. Clive Barker began his career as an actor with Joan Littlewood's Theatre Workshop, appearing in both The Hostage and Ohl What a Lovely War, and was Festival Organizer on Arnold Wesker's Centre 42 project. He left his first academic post at the University of Birmingham to direct for the Northcott Theatre, Exeter, but in 1975 began a second academic career at the University of Warwick. His publications include the seminal and widely influential study-cum-training manual, Theatre Games. He joined Simon Trussler as Associate Editor on the original Theatre Quarterly in 1978, and both were involved in the journal's successful endeavour to recreate a British Centre of the International Theatre Institute.
\end{abstract}

\section{Simon Trussler}

\section{Confessions of a Compulsive Editor}

MOST of my working life has been shaped by or around editing Theatre Quarterly and New Theatre Quarterly. I suppose NTQ is now generally categorized as an 'academic journal': but when I myself became a full-time academic in 1987 it was well after the death of the old Theatre Quarterly and the launch of the new - while my colleague Clive Barker enjoys the rare distinction of not having had a degree when he was appointed to his first university post. Editing the journal, along with writing books about the theatre, were at first just enjoyable ways of earning a living; only later did such activities earn academic brownie points, and their continued pursuit become desirable in the interests of research assessment.

During my decade as a 'proper' academic, I found that my own views of the purpose of a university education - and of the function of theatre studies within it - were becoming increasingly regarded as improper. Feeling ever more disenchanted and exhausted, I took early retirement, in company with two colleagues of similar vintage. NTQ's own network happily provides continuing contact with what still seems to me important about the discipline; and what I have learned on the hoof over thirty-odd years about the practical side of editing and typography now qualifies me to re-establish and broaden other kinds of contact. It has been good not only to write once more for pleasure rather than to fit a 'profile', but to find that my mix of old-fashioned scruples and new-fangled 
technological know-how commands respect (and, dare I say, even market value) in the world of theatre publishing.

Looking back at my valedictory editorial in TQ40, the final issue of the original Theatre Quarterly, I see that I then apologised for adopting 'a more personal tone than TQ has usually allowed'. Although such an apology should perhaps be repeated here, with the happier excuse of our centenary issue, it was arguably a bit cheeky at the time - since all three editors of the old journal had, in their varying permutations, regularly bared their souls to a long-suffering readership, sometimes in unconcealed contention in what we used to describe as 'editorial dialectics'.

Those dialectics - and less explicitly the journal itself - reflected the conflicts of belief as the generation which chronologically or spiritually affiliated itself with the 'spirit of 1956' rubbed shoulders with the exponents of the 'spirit of 1968 '. The end came, aptly enough, in the wake of the first Thatcherite election victory, when it was already clear that some of the debates had been both misdirected and self-indulgent - for the postwar consensus which many had been blithely challenging from the left was now coming under far more effective and ultimately destructive attack from the right.

But if the old Theatre Quarterly now seems rhetorically very much of its time, perhaps even the rhetoric should be read alongside the still valid documentation and re-evaluation which formed the core of the journal as part of the record and retrospect it constitutes. For TQ had its origins in the conviction that what was happening in the theatre mattered, but was not being very adequately debated or at all adequately recorded.

\section{From Rectilinear to Curvilinear}

All three of the journal's founding editors Roger Hudson, Cathy Itzin, and myself were recent graduates of University College London (where I had myself learned to set type on the English Department's cherished Elizabethan-style printing press). All of us had been involved in Prompt, a 'little' theatre magazine started by Kenn Stitt and myself, with the support of the college's Dramatic Society.

Like so many others, I cut my professional teeth on the vintage Plays and Players under Peter Roberts - another compulsive theatre editor, thankfully still going strong - before, in 1966, succeeding Clive Goodwin as one of the editors of Encore. A fellow editor, Charles Marowitz, collaborated with me on Theatre at Work, a sourcebook of 'new wave' theatre commissioned by Methuen, where Geoffrey Strachan had recently succeeded John Cullen as presiding genius over a drama list generally recognized as embracing the best of new theatre writing. Roger, Cathy, and I got back together, and with the hubris of youth put forward the idea of Theatre Quarterly as a jewel for the Methuen crown.

The proposal and the early issues were conceived and plotted in the pubs of the university and theatre districts of London the Marlborough in Torrington Place, the Carpenters' Arms off Fitzroy Square, the George off the Strand, the Buckingham in Petty France. The donkey work was done, on a rather reluctant rota, successively in an office in Goodge Street (where the folk who edited the revolutionary African Communist proved excellent neighbours), in short-stay premises in Chalk Farm, and finally from Covent Garden, where a canny but sympathetic landlady kept us one block ahead of the redevelopment already lapping northwards around the Cambridge Theatre.

By this time, the accountants at Methuen had vetoed the renewal of our three-year contract, and after a brief but costly attempt at rectilinear independence, we had entered into a curvilinear and always ambiguous association with one of the stranger outcrops of the 'spirit of 1968'. This, anticipating its own wilder dreams, called itself the Institute for Research into Art and Technology - one of the many co-operative outfits of the time, comprising a typical mixture of dedicated stalwarts and amiable drifters. It was held together with a blend of charm, chicanery, conviction, and irredeemable optimism by Michel Julian, himself an alternative outcrop of no mean proportions, and a radical Europhile ahead of his time. 
So three upwardly-mobile editors, in the throes of acquiring mortgages and children, found themselves with equal voices in endless meetings to discuss such vitals of the coming revolution as the floor-sweeping rota and who should have a key to the stationery store (analogous trivialities were in due course to become endemic at academic department meetings). Two of the editors dropped out probably more ideologically in tune than myself, but less able to cope with the personality conflicts and office politics.

My own saving grace was, I suspect, that I had always been as much interested in the how as in the why of magazine production. Indeed, I had been in love with print and all its mysteries since the age of nine, when I was taken (during a first visit to London for the Festival of Britain) to see the old Co-op Sunday broadsheet Reynold's News going to press. I was especially awed by the massive Linotype composing machines with their tantalizingly complex keyboards, on which I was permitted to tap out long-cherished slugs bearing my own name and address.

On a slightly more leisurely basis, that was close to how Theatre Quarterly was first composed - in hot metal on the Monotypes of Eyre and Spottiswoode's Grosvenor Press, but on basic principles which Gutenberg and Caxton would still have recognized as their own. No doubt as a precaution against excessive authors' corrections, Methuen shepherded us to Portsmouth to stare in wonder at the wall of type locked up in trays which constituted a single issue of the magazine. Today we can fit a single issue of New Theatre Quarterly, digitized illustrations and all, onto a five-inch Zip cartridge.

We were already sniffing a false dawn of what would now be called desktop publishing back in the mid-seventies, when the need to do-it-ourselves saw camera-ready copy for TQ being produced with the help of a top-of-the-range IBM Composer, sheets of Letraset, scalpels, and the clinging odour of Cow Gum. Never mind ideology: this was control over the means of production - finetuned by the new IBM Selectronic with its correctable memory, equivalent to a galley proof of type. The only drawback was that now vanished repetitive strain injury, golfball thumb - a painful parting of flesh from cuticle caused by the constant switching of the little globular fonts of roman, italic, and bold. Later issues were produced by fullyfledged photocomposition on a Linotronic a nicer product, but a backward step in the evolution of desktop technology.

\section{Ideologies and Institutions}

While such technical niceties were occupying us behind the scenes, front-of-house Theatre Quarterly was quietly helping to shape now familiar directions in theatre studies. Forms of popular and working-class theatre were a concern from the first, with the concomitant opening up of nineteenthcentury studies and broadening of the base of what constituted performance. Some of the early 'Casebooks', as we dubbed our then-innovative sequence of production logs, probably seem impressionistic now, and to be lacking (weren't we all?) in theoretical rigor; but even while we sought for (and intermittently tried to develop) a vocabulary for theatre studies which would permit greater specificity and objectivity, we stuck to our initial declaration that if the journal were to bridge the gap between academic and professional theatre, the professionals must be enlightened and not mystified by what the academics wrote.

Indeed, it was not mainly to the academy that we were looking to bridge the gap, but to bodies in which the profession would be serviced rather than subservient. Early on, we mounted a campaign to establish a British Theatre Institute, analogous to the British Film Institute: but no sooner was its embryo formed than it got bogged down in its own committees, and by the competing interest groups represented on them. Learning that lesson, we sought to retain control if we were also to provide resources for a new British Centre of the International Theatre Institute: that hope vanished along with the old TQ. The British ITI Centre survives, but with services and resources unequal to its potential.

In those days before the Internet or CDROM storage technology, we also tried - on 
a scanty, card-indexed, human sort of scale to offer resources of factual and bibliographical reference which were highly labour intensive. A succession of spin-off publications Theatrefacts, Theatrelog, the Theatre Checklist series, and an Annual Bibliography of Theatre Studies - were launched when such materials threatened to engulf the journal; and even the Alternative Theatre Directory began as a small pamphlet under our imprint.

Of course, we were so busy producing all these journals and espousing all those brave, doomed causes, that we had little time left for building an adequate subscription-base; and although the University of East Anglia generously provided us with an office and an assistant to run it - the indefatigable $\mathrm{Liz}$ Edwards - we could neither afford nor were we properly enthused to conduct circulation drives. After all, we did everything else, didn't we? The least other people could do was subscribe. ... And then, in a side-swipe of which few but fellow-sufferers at the time were probably aware, some early Thatcherite decision-making at the Arts Council cut off funding to Theatre Quarterly and other 'minor' clients: it had been barely a trickle, but it had just made the difference, and the old TQ disappeared.

\section{Varieties of Academic Experience}

My colleague Clive Barker, whose editorial follows this - the reversal of our usual alphabetical order here making better chronological sense - takes up the story of the journal's happy restoration, under conditions which have allowed editors to edit, and not to get too stressed by the nuts and bolts of promotion and distribution. This was not without some initial scepticism on my part, when I recalled how brief had been our first encounter with a commercial publisher. Thankfully, Cambridge University Press is not a commercial publisher, and in all its dealings with us has remained 'academic in the best sense'.

In what is now a fifteen-year association, CUP has never once questioned an editorial decision, has quibbled with only a single phrase in a single article (on grounds of possible libel), and has proved seamless to work with - especially since 1989 , when the now accomplished desktop publishing revolution enabled us to take pre-press production of the journal once more 'in house'. (On the day of the Cambridge meeting at which that was agreed, the idea of my writing The Cambridge Illustrated History of British Theatre was also mooted, and also seen through to a happy outcome 'in house' - the house in question being my own successive country dwellings in Kent.) This editorial provides a welcome opportunity to pay tribute to the helpfulness when needed, and the forbearance when not, of the Journals Department at Cambridge University Press.

It seemed logical enough for me to complement this new association with a formal academic role, and for a while that relationship also proved 'academic in the best sense', under a Head of Department at Goldsmiths College who worked hard on behalf of her whole team, in the belief that people should be encouraged to do what they were best at doing. Inexorably, however, the generation of fully Thatcherized academics and administrators edged their way into most positions of power, implementing the conviction that anybody who thought, behaved, or had any kind of ambitions which were not marketled and business-based (or worse, dared to have no ambitions at all) had to be thoughtpoliced into line - or, like the miners and others, into the dole queue.

Some believed themselves immune from such effects; and one of the most depressing features of British university life in the early 'nineties was thus witnessing the metamorphosis of old left-wing colleagues - often further to the left than I ever was, when the pendulum of fashion so swung - from caterpillars declaring that they must crawl their way into the system in order to beat it, into moths dutifully nibbling away at the freedoms they had once cherished.

I had, before this process was complete, risen through the ranks to a readership, about which I had assumed there to be something life-defining. F. R. Leavis and Raymond Williams, though belatedly elevated, were among those who had seemed formed by 
nature for that mould - one which remains as mysterious to the average non-academic Englishman as to the average American academic. But the then-Warden of Goldsmiths told me at the time that it should now be regarded more as a promotional steppingstone, from which one might in the fullness of time be expected to be elevated into the comfort of a chair. I therefore took my own failure to secure such consolation as a due rebuke for getting too uppity. The College and I parted with mutual relief nearly three years ago. I have had just one personal communication under its letterhead since - from the Library, demanding twenty pounds for unreturned library books.

\section{Eclecticism and Eccentricity}

If I am conveying an impression of a cantankerous spirit successively falling out with fellow editors and fellow academics, it may be a useful moment to reflect that the now twenty-year editorial relationship between Clive Barker and myself has throughout that time been friendly, often funny, and always mutually respectful. Now, it has become almost symbiotic. Thus, we both instinctively know which articles are going to be to our mutual taste even before they cross in the posts between Kent and Warwickshire - or are exchanged in the foyer of the Lyttelton, which has become our central meeting point. We know the subjects and approaches where one is going to defer to the other - or those where we both shrug our shoulders and pass the buck to one of our specialist advisors. We also sense in advance which articles we don't personally like, but which may appeal to the other-requiring the advocate either to defer, or to invoke the unwritten prerogative that one editor's strong personal gut reaction may occasionally be allowed to override the other's doubts.

We are, in short, proud that NTQ remains an edited not a 'refereed' journal, allowing us our eccentricities and giving the journal a more positive personality than that of a camel. 'Well, if we don't publish it, nobody else will,' is often an inducement to squeeze in the thought-provokingly off-beat rather than a temptation to conform to academic taste. But this does not shape the journal in our image - or if it does, we must both be shape-shifters. For it is the sum of our contributors who create the 'image' of New Theatre Quarterly - more than they did that of the original journal, which we tended to be proactive in moulding to our tastes. Then, we knew what we thought, and we wanted others to think in the same way: now, we still know what we think, but are sufficiently confident about it to encourage all-comers not least because of a climate in theatre studies which otherwise discourages creative dabbling in an eclectic range of areas and interests.

Indeed, we are resolute in being generalists during an age of specialisms. Clive is a professional actor, director, and trainer. I am a professional writer, editor, theatre historian and critic. My Master's degree was on an eighteenth-century topic, my Doctorate on a nineteenth; my earliest publications were on contemporary drama, while my later output has been largely in the Elizabethan and Jacobean field. The personal (like the editorial) instinct is always to move on rather than to delve ever deeper - to make connections and understand perspectives rather than to claim the last word in an argument in a one-way street. But the day of the generalist theatre scholar is probably over - for the system is increasingly squeezing its younger members into specialist corsets to fit the departmental profile (unless the 'generalist' is appointed at the lowest end of the scale, to read up on his or her latest generality the night before the seminar). It is all the more important that the generalist theatre journal survives.

It's important, too, that breadth of scope is matched by breadth of outlook. We still include articles in the 'New Critical' tradition while also publishing - as it happens, in this issue - an article adversely critiquing its effects upon the older generation of theatre reviewers. In a recent issue we published what many specialists no doubt regarded as a rather unscholarly account of coming to terms with Brecht, because - while it was self-evident in places to those of us schooled in the 'sixties - it seemed to us to reflect with 
sympathy, perception, and finally with understanding the opaque image of the man as received by students and young actors today.

There was not a word or indeed a paragraph in that article which could not have been readily understood by a sixth-former. I confess there are other articles we have published which I have had to reread several times before attempting a serious judgement, because while they clearly had something to say, they employed a terminology which was wrestling to express the previously inexpressible or the otherwise ambiguous. (In articles we do not publish such specialist terminology turns easily to obscurantist jargon.) For the terminology we need, we are now ranging further afield, and borrowing from all sorts of other disciplines - some scientific, rather than from the humanities whence most of us came. But after almost thirty years, the search is still very much in progress.

Since this is in large part because the language of the craft we study is visual as well as verbal, I seldom fail to be surprised when a contributor hoping with whatever degree of success to give verbal shape to a piece of live art or a long-dead performance appears to have given no thought to the iconographic potential - obscurantist jargon for using relevant pictures. As a wordsmith myself, I share the feeling that the tools of my own trade should suffice; for that matter, I identified with all the old print craftsmen locked out at Wapping - but I knew that their cause was doomed not (like that of the miners) by ideology, but by technology. (It is the technology that has just allowed me to download from a site in Japan new drivers to make my scanner compatible with my new computer, which, quite apart from its instant access to the riches and rubbish of the Internet, is itself faster and has more capacious storage than any layperson could have comprehended ten years ago.)

But if the new technology is not to spell the death of the printed word as spread through the book (and the journal), those who write about theatre must, of all people, learn how to integrate their writing expressively with the new technology - and rather more quickly than they appear to have learned to integrate it with that now rather old technology, the half-tone photograph. In talking, as we rightly do, about finding a language for theatre studies, it is at our peril that we take the term too literally.

\section{And How Did You Enjoy the Play?}

I have encountered few who left university life under circumstances similar to my own who have felt a moment's regret. Of those who taught Theatre Studies, many were of an age when one went into academic theatre via live theatre rather than doctoral research, and they, largely with relief, have been able to return to theatre for a living.

In my own case, the return being to the world of theatre writing and publishing, I think I can stake a claim to be the first bibliographical and textual scholar - an editor for publication of plays from the sixteenth through the twentieth centuries who has also undertaken the typesetting of plays professionally. Thus have I learned at first hand the contemporary equivalents of all those problems relating to foul papers and fair copies, or with distinguishing authorial practice from printing-house intervention or, as it might be today, digital corruption. (Thanks to the disastrous Microsoft Word 'Fast Save' option - disable it, my friends one playwright had the eery experience of receiving his play in proof in a version he believed to have been wiped from his drive four weeks previously.) One day I shall write an article for NTQ about it.

One of the practical problems of putting many 'nineties plays into print is transliterating demotic speech modes in ways that do not resemble Shaw's largely embarrassing attempts at phonetic Cockney. This forcibly reminds me that what I hailed as 'workingclass' plays in the years when I was first encountering theatre were, generally speaking, really plays about people like myself working-class in origin, but blessed by the post-war consensus to be educated out of our stations, and so destined to debate our declassing with an articulacy that was part of the middle-class veneer those educations were meant to supply. 
Today, play after play is about not so much the working class as the underclass, and delineates an existence compounded of fear, rat-cornered aggression, dependency, and real or emotional drudgery. In these plays, the poetry is not in the sparse vocabulary but in the pity - or at least the empathy enforced upon audiences still largely snug in their middle-class cocoons. These plays rarely offer more than a glimpse of hope through love or self-discovery, and do not aspire to offer solutions. At the other extreme, live art and other postmodern forms of what we used to call the avant-garde titillate jaded sensibilities with the audio-visual equivalents of crossword puzzle grids - full of patterns and surrounded by clues which at once imply and deny a meaning to the patterns.

With a resolute belief that theatre can effect social change, I yet recognize the force of Irving Wardle's wry assertion in a recent NTQ that if it truly had that power, the hard core of inveterate first-nighters 'would have been the most virtuous people in the land' instead of among the dreariest. How today's 'in-yer-face' theatre connects with many of their lives I really cannot imagine - and I have to confess that in many ways it disconnects from mine. This is perhaps as it should be: if such theatre spoke with urgency to an erstwhile academic in late middle age, something would surely be amiss. But how does it connect with the lives of those in the age group when Look Back, Roots, and Musgrave were making their very different connections with mine? New Theatre Quarterly has not been offered many articles which attempt even sideways answers to that question, but I pose it in sincerity not in sarcasm.

\section{Coda}

As I re-read this article in draft, I register how closely the editing of theatre magazines has run in parallel with my personal life. I met my first wife at a college tea to recruit for Prompt, and our twin children were born as the first issue of Theatre Quarterly was being assembled. That journal ended alongside my first marriage, and the first issue of New Theatre Quarterly was being put together at the time of my second - the birth of the journal being closely followed (for both editors, as it happens) by the arrival of offspring who have not known life without the slow but insistent beat of their fathers' quarterly deadlines. If those seminal plays and their like had not been there in the late 'fifties and early 'sixties, I really do not know how I would have made my living. I remain surprised and grateful that, however precarious and fraught that living has often been, the theatre has provided it - with TQ and NTQ always close to its personal and philosophical, if not to its economic core.

\section{Clive Barker}

\section{Different Kinds of Strength}

WHEN the first issue of Theatre Quarterly was announced, I was asked by John Russell Brown: 'Do you think it will be any good?' I replied that a strong theatre journal needed a strong theatre. Before Theatre Quarterly, Encore had been started at the most remarkably apposite time. Whether Encore in some way promoted the breakthrough or was indicative of submerged forces which surfaced in May 1956, it was nevertheless conveniently in place to acknowledge its changing function - dropping the solemn banner of 'A Quarterly Review for Students of the Theatre' between No. 6, dated Easter 1956, for 'The Voice of Vital Theatre' by No. 9, which appeared in Summer 1957.

Encore flourished by finding a strong theatre movement, led by the new generation of playwrights - with an injection of ideas from continental theatre, which had significantly been ignored by the British theatre since 1918. When the sources which nourished Encore faded, the magazine lost energy and closed. Theatre Quarterly lacked the advantage of being in existence before the new movements began - as is reflected in the gaps in the attempt to chart the growth of 
Today, play after play is about not so much the working class as the underclass, and delineates an existence compounded of fear, rat-cornered aggression, dependency, and real or emotional drudgery. In these plays, the poetry is not in the sparse vocabulary but in the pity - or at least the empathy enforced upon audiences still largely snug in their middle-class cocoons. These plays rarely offer more than a glimpse of hope through love or self-discovery, and do not aspire to offer solutions. At the other extreme, live art and other postmodern forms of what we used to call the avant-garde titillate jaded sensibilities with the audio-visual equivalents of crossword puzzle grids - full of patterns and surrounded by clues which at once imply and deny a meaning to the patterns.

With a resolute belief that theatre can effect social change, I yet recognize the force of Irving Wardle's wry assertion in a recent NTQ that if it truly had that power, the hard core of inveterate first-nighters 'would have been the most virtuous people in the land' instead of among the dreariest. How today's 'in-yer-face' theatre connects with many of their lives I really cannot imagine - and I have to confess that in many ways it disconnects from mine. This is perhaps as it should be: if such theatre spoke with urgency to an erstwhile academic in late middle age, something would surely be amiss. But how does it connect with the lives of those in the age group when Look Back, Roots, and Musgrave were making their very different connections with mine? New Theatre Quarterly has not been offered many articles which attempt even sideways answers to that question, but I pose it in sincerity not in sarcasm.

\section{Coda}

As I re-read this article in draft, I register how closely the editing of theatre magazines has run in parallel with my personal life. I met my first wife at a college tea to recruit for Prompt, and our twin children were born as the first issue of Theatre Quarterly was being assembled. That journal ended alongside my first marriage, and the first issue of New Theatre Quarterly was being put together at the time of my second - the birth of the journal being closely followed (for both editors, as it happens) by the arrival of offspring who have not known life without the slow but insistent beat of their fathers' quarterly deadlines. If those seminal plays and their like had not been there in the late 'fifties and early 'sixties, I really do not know how I would have made my living. I remain surprised and grateful that, however precarious and fraught that living has often been, the theatre has provided it - with TQ and NTQ always close to its personal and philosophical, if not to its economic core.

\section{Clive Barker}

\section{Different Kinds of Strength}

WHEN the first issue of Theatre Quarterly was announced, I was asked by John Russell Brown: 'Do you think it will be any good?' I replied that a strong theatre journal needed a strong theatre. Before Theatre Quarterly, Encore had been started at the most remarkably apposite time. Whether Encore in some way promoted the breakthrough or was indicative of submerged forces which surfaced in May 1956, it was nevertheless conveniently in place to acknowledge its changing function - dropping the solemn banner of 'A Quarterly Review for Students of the Theatre' between No. 6, dated Easter 1956, for 'The Voice of Vital Theatre' by No. 9, which appeared in Summer 1957.

Encore flourished by finding a strong theatre movement, led by the new generation of playwrights - with an injection of ideas from continental theatre, which had significantly been ignored by the British theatre since 1918. When the sources which nourished Encore faded, the magazine lost energy and closed. Theatre Quarterly lacked the advantage of being in existence before the new movements began - as is reflected in the gaps in the attempt to chart the growth of 
'underground theatre' in the first issue of January 1971 (though these had been filled by the twelfth, with its 'Potted History of the Fringe').

So Theatre Quarterly emerged running, trying to catch up with the new ideas that were pouring out from the alternative theatre (which one of the original editors, Catherine Itzin, was later to map in her extensive book, Stages in the Revolution). When the false dawn faded and Thatcher turned a cold, less romantic light on progressive and cooperative changes in the theatre and society, Theatre Quarterly lost a lot of its nourishment along with the Arts Council funding which proved its death blow in 1981.

But there was more to the closure than a simple loss of function, which was obviously also the case with Encore. At the moment it closed, Theatre Quarterly was evolving new policies and, to my mind, was becoming much stronger as a journal as each issue improved on the last. It was also expanding to take on new functions - the Theatre Checklists, for example, providing material aid to those teaching the contemporary theatre, British and international, in schools, colleges, and universities.

With a small staff, the journal took on the task of reviving the suspended British Centre of the International Theatre Institute and bringing the British theatre back onto the world scene, as it had earlier taken the leading role in attempting to bring about the founding of a full-scale British Theatre Institute, which would have united all theatre organizations in an attempt to give the theatre the strength to speak with one voice. Theatre Quarterly, of which by then I was Associate Editor, closed because the work load became oppressive and took away time and energy from the problems of distributing the journal. As issues advanced in quality, they reached a shrinking readership.

The later issues of Theatre Quarterly show that many of the lines running through the earlier issues continued, but there are also new concerns and new emphases. There are earlier articles on Africa, but the magazine begins to abandon its Eurocentric emphasis around TQ 28, with the range of articles beginning to spread more widely. There is an increase in material on community and educational aspects of drama and theatre. Articles dealing with analysis of performance begin to establish ways of looking at and considering process, and there are a number of articles which go beyond surface description and try, through analysis and interview, to probe deeper into how playwrights structure their work and theatre groups devise their shows. Looking through the make-up of the old TQ, as indexed later in this present issue, it is surprising how many articles are based on revisiting crucial plays and performances in the historic past.

\section{The New Beginnings}

In 1984 I was approached by Sarah Stanton of Cambridge University Press and asked, 'Why did Theatre Quarterly close?' I gave pretty much the analysis I have given above. She then wrote and asked, 'Shouldn't it be started again?' I asked a further question of her: 'Are you asking if I would edit it?' I was at that time suffering badly from arthritis which was making performance and teaching work very difficult, and I was seeking alternative ways of staying in the theatre. I answered my own question by saying that I would be very interested in editing the journal, on condition that Simon Trussler agreed to join me as co-editor. He did.

We began with four policy objectives, which derived from the past experience of editing Theatre Quarterly, now mediated by working in a different period and inside a different publishing structure. Theatre needs a philosophy. Theatre studies need a methodology. Criticism needs a language. Theatre history has a contemporary relevance. We decided against studies of plays and playwrights, principally since the rich seam of new playwrights who emerged after 1968 was drying up, existing playwrights were not coming out with much that was new, and, in any case, other journals were already supplying that need.

There are many strengths to being with a major academic publisher, not the least being that your issues come out on time. (Of the sixty issues of New Theatre Quarterly, two 
have come out before they were due, fiftyseven have come out on time, and just one came out a few days late, because of a problem with the cover - a record of which we are very proud.) But the schedules of a major publishing house do not allow us to be topical, and we had of necessity to decide that we could no longer make an immediate input into the theatre.

We have concentrated, in line with our aims, in clarifying in as detailed a way as we can the context in which the contemporary theatre is created. While I was sitting on a panel evaluating student work in a drama department, the question was put to one of them: 'The whole direction of this course is towards what is happening in the theatre today. Where do you find the materials to study?' 'When I started on the course I wondered how I would find them, then one of the tutors showed me New Theatre Quarterly.' In that respect we have contributed more to the advancement of the study of the theatre than to its practice.

This we have tried to do through articles on the methods by which acting is taught and the means being employed. We have thought this a vital function, as it seems that theatre studies, particularly in universities and colleges, are badly in need of a methodology. The old purpose of combining study with practice and history as a continuous developing process seems to have been discarded. The understanding of the modern theatre has diminished in favour of an emphasis on postmodernism - which should not be ignored, but within which there are clear dangers if it is not contextualized within the developments against which it rebels. There is also the question of performances which give no importance to character, plot, or action, and appear, within student or novice work, to be totally self-justifying, regardless of the audience.

New Theatre Quarterly, possibly because of its own and its editors' advancing years, is resolutely modernist, surrounded by a profusion of postmodernist alternatives. We have published many articles which introduce new ideas from within our perspective or formulated new analytic tools, but we have tried to ensure that new explorations are expressed in language which can be understood not only by the detached critic but by performers. One phenomenon of the postmodernist approach is that frequently you find students who know their Lacan, but to whom Brecht remains a mystery. Our modernism follows Edward Gordon Craig and his advice that the reason that new impulses in the theatre fade and die is that they don't know the history out of which they grow, nor the context in which they operate.

We have also tried to be true to the later Theatre Quarterly by spreading our coverage as worldwide as we are able, and we have taken on board many articles which deal with new areas of concern and advancement outside the mainstream - gender performance theories and critical evaluation, educational changes and initiatives, and questions arising out of the developing relationships between theatre and the wider community which is its setting.

We have never operated too strict a policy line. Often we have edited on the principle that if someone has something to say which they believe in, we have let them say it. We have not clung to a line of strict academic respectability. I am deeply sorry not to have had an article on Sally Rand, the actress who invented the Fan Dance at the Chicago World Fair. At the back of my mind is the idea that I want to edit a journal which is academically acknowledged but can be read on a train journey - and I think two issues have come near this.

We have a policy, but it emerges from selection and not from dogma. This is largely possible because of the length of time that Simon Trussler and I have worked together over the years. We complement each other rather than duplicate. Occasionally we are asked about the feverish discussion we have at editorial meetings. But we live in different parts of the country, and have only had a handful of 'live' editorial meetings in the last four years: we edit by exchanges of scribbled notes and shorthand telephone calls. It is a relationship of total trust and, in my experience, unique. Either of us can, on occasion, 
make a decision without consulting the other. Disagreements have only been minor, very rare, and are settled in favour of the proposer, never the opposer. Maggie Gale operates the book reviews with total independence and total efficiency.

The world is changing, and the theatre with it. And New Theatre Quarterly will have to change also, or lose its function. With only three, widely spread, people running the show, this is becoming difficult. We have always had a reserve of articles in hand, and there is no sign of this drying up: but in this sense our existence relies upon our writers keeping pace with new developments in the theatre. We can only encourage them. We have a cohort of longstanding contributors, but the present situation does not allow younger members of academic staff sufficient time off for research. There is no shortage of talent, but the areas of publication are becoming increasingly restricted. The situation is iniquitous, as younger staff get caught between unduly heavy teaching loads and the pressure to publish.

\section{The Changing Pattern}

The present situation in the theatre is full of new initiatives and ideas, but it is much more fragmented than before, and it is hard to keep pace with. Five years ago, at a conference on Popular Theatre at Liverpool John Moores University, I flew a kite, giving a plenary address which I entitled 'The Silent Revolution', in which I said that I sensed that there was growing up a whole new pattern of small theatre companies in this country, mainly content to work out of regional communities, and not oriented to moving to London. I forecast the decline almost to extinction of TIE, if it continued to present issue-based participatory performance, in the face of new, more relevant and effective forms of community and educationally based theatre.

I have the luck to live near a place Coventry - where I can see this happening, with the Belgrade Theatre providing umbrella support for a considerable number of local companies, adult and teenage. The pattern is emerging for an entirely new relationship between the theatre and the community in which it lives and operates. And the critical acclaim for Theatre Absolute's Car and for Triangle's Looking for the Talleyman at this year's Edinburgh Festival should ensure that we are not dealing here with the dilettante or second-rate - nor can I believe that it is only happening on my patch. In fact, I know there is a flourishing theatre scene in the NorthEast. But what is happening elsewhere? Who will chart these areas for us? What we want urgently is a comprehensive picture of all the Silent Revolution companies, their work, what is impeding them, their needs, and what pressure can be applied for funding to sustain them. Don't let the regions be starved of support again. And let the subsidy go to the most advanced causes.

This year's London International Festival of Theatre had very few companies with a conventional narrative text. There is a great deal of fragmentation in Europe and, unless the means can be found for Dragan Klaic to revive Euromaske, no one seems to be charting this development. We'll try, but help is needed - and there are causes where support can only come from public action. In my experience there is a great wealth of talent in the drama schools, and the state of British actor training is stronger than it has been in my memory. All manner of concealed plans are being made in government to restructure, move, close, or promote drama schools which are likely to jeopardize a standard of training which is the envy of most of the world. We will try to cover what we can of the issues involved in all these areas, but again we need help.

Soon we will publish a comprehensive coverage of the Coventry pattern and companies, and hopefully extend this to other localities. In Britain, the playwrights are emerging again as a significant force and we will amend our policy to cover what is happening. However fragmented, the theatre is once again becoming a strong theatre. In an early issue we shall be listing the thirty articles we would most like to publish in order to open up the analysis and discussion of these strengths. Please write them. 